\title{
The Impact of Exposure to Diversity in the International University Environment and the Development of Intercultural Competence in Students
}

\author{
Jeanine Gregersen-Hermans
}

\section{Internationalization as an Institutional Strategy for Intercultural Competence Development}

One of the early and most common internationalization strategies implemented by higher education institutions to develop intercultural competence in its students is study abroad or student mobility (Teichler 2007a, b; Teichler et al. 2011; Wächter and Ferencz 2012). Related to the limited number of students and staff that can be reached through mobility, the focus of the strategies for developing intercultural competence within the higher education institutions shifted from offering courses in English for exchange students and stimulating student and staff mobility, to internationalization of the curriculum including an international and or European dimensions and perspectives in the substance of learning (Teekens 2006; Teichler 2007b; Van der Wende 2002); and to international marketing and student recruitment (Van Rooyen 2008; Van Vught and Rogers 2006) diversifying student and staff populations on campus and, thereby, addressing also non-mobile students and staff. The new adagio 'internationalization at home' has quickly gained ground since then (i.e. Beelen 2007; Mestenhauser and Ellingboe 1998; Mestenhauser et al. 2003; Nilsson and Otten 2003; Teekens 2007; Teichler 1999). Study abroad aims to give mobile students the exposure to a culturally different environment, while at the same time home students are assumed to benefit from the international classroom.

However, in an INSEAD working paper Hawanini (2011) raises serious concern if transformation towards truly global universities actually is taking place. Leask (2009, 2010) argues that a commonly observed form of token 'cultural tourism' by inserting some entertaining international examples in the course content is deemed insufficient to achieve international and intercultural learning outcomes. The need

\footnotetext{
J. Gregersen-Hermans ( $\square$ )

University of Hull, Kingston upon Hull, UK

e-mail: j.gregersen@hull.ac.uk

(C) The Author(s) 2015

A. Curaj et al. (eds.), The European Higher Education Area,

DOI 10.1007/978-3-319-20877-0_6
} 
for proven effectiveness of the internationalization activities that go beyond the impact on careers and labour market mobility (see for instance de Wit 2011; Deardorff 2009a) has increased in recent years. In the discourse on internationalization shifts can be observed from outputs in terms of internationalization activities to outcomes of these activities, for instance in terms of intercultural competence development and how this is assessed. Both in terms of accountability and impact of activities, the current discourse expresses the need for studies that clarify the relationship between the internationalization activities in higher education and its desired outcomes, like intercultural competence (Berg et al. 2012; de Wit 2011; Deardorff 2009b; Deardorff et al. 2012). The studies on assessing the impact of internationalization for developing intercultural competence (Alred and Byram 2002; Berg et al. 2012; Paige et al. 2003, 2009; Peppas 2005) however, primarily focus on study abroad and student mobility, on intercultural learning at the classroom level, on the experience and acculturation of individual students (Deardorff and Jones 2012; Smith and Khawaja 2011). Although some factors seem to influence the development of intercultural competence, such as immersion into the host culture, length of stay, previous experience abroad and language ability (i.e. Graf 2004; Littrell and Salas 2005; Paige et al. 2009; Vande Berg et al. 2009), the evidence for competence development in students is inconclusive (Berg et al. 2012; Hammer 2009, 2011). Bennett in Berg et al. (2012) clearly states that intercultural learning is not something that automatically occurs because of study abroad. Cross-cultural contact does not lead to intercultural learning per se. Even though students might have a transformative learning experience when studying or volunteering abroad (Jones 2010), this does not imply that they had an intercultural one (Bennett, in Berg et al. 2012). Many publications on the impact of these intercultural and international experiences primarily rely on self-reports of participants, which include increased knowledge of the host; increased awareness of the own cultural background; increased awareness of cultural different perspectives and respect for other cultures culture (Alfranseder et al. 2011; Jones 2010; Leask 2009; Montgomery 2010). It is not clear however to what extent these international or intercultural experiences actually led to intercultural learning. Assessment of intercultural competence development is a more recent trend, among others inspired by the Georgetown Consortium Project (Paige et al. 2009), which demonstrated the need for intentional and guided development of intercultural competence.

In recent years concern also has been raised about the international classroom as an effective strategy for the development of intercultural competence of both foreign and home students on campus (Harrison and Peacock 2010; Leask 2009; Thom 2010). More specifically, Leask (2009) argues that the development of intercultural competence rarely is an automatic outcome of cultural diversity in the classroom, and a campus culture is required that enhances interaction between international and home students. However, universities struggle with the integration of home and foreign students in and outside this international classroom due to stereotyping, lack of knowledge about the background of culturally different classmates, language issues and the desire to stay in the own cultural group (Harrison and Peacock 2010; Montgomery 2009). Montgomery (2009) found that 
student's views on working in multicultural groups with an "AfL approach" were more positive than a decade ago and perceived as adding value to their learning experience. Others (see for instance $\mathrm{Li}$ and Campbell 2008) reported negative perceptions of students to intercultural group work. ${ }^{2}$ Montgomery (ibid) concludes that the wider context of the learning environment might influence the student's perceptions. Kimmel and Volet (2012) found that "even when language was not an issue, students still preferred to work in non-diverse groups". Outside the classroom the interaction between the various groups of students seems limited; students seem to interact primarily with students from their own country of origin or in case of foreign students with other foreigners. A survey of the Erasmus Student Network (ESN) (Krzaklewska and Krupnik 2006) offers supporting data. Although the foreign students in the ESN study reported high levels of satisfaction with what they learned about the culture of the host country (92\% highly satisfied), high levels of satisfaction regarding their interaction with other foreign students, they were less satisfied with the contact with the local students $( \pm 50 \%)$ (Krzaklewska and Krupnik 2006, p. 43). The latest ESN study (Alfranseder et al. 2011) reports similar trends. Although Erasmus exchange students are highly satisfied with the experience, they report less satisfaction on the issue of integration into the local community.

Despite these concerns and research findings, the daily practice in higher education informs it still is the implicit assumption of many HEI policy makers that exposure to diversity automatically will give the participants in university activities a sufficient degree of intercultural competence to maximally gain from the internationalization process. European universities have continued to engage in international partnerships for education and research; increased international student mobility and have grown their international student population (European University Association 2013) to provide their students with an international experience and, thereby, implicitly assume to enhance their competence to function effectively in a globalized world. The 4th Global Survey of the International Association of Universities (Egron-Polak and Hudson 2014) confirms this finding for universities world-wide. Although higher education institutional leaders mention 'students' increased international awareness and engagement with global issues' as the number one benefit of internationalization, the priorities for achieving these are mainly output based, such as mobility and increasing diversity on campus. De Wit (2011) refers to this approach as one of the nine misconceptions on internationalization of Higher Education. Bennett (in Berg et al. 2012) frames this as the traditionalist view (p. 91) on internationalization of education.

In this context, the question arises whether one also comfortably can state that universities deliver on the rationale for intercultural understanding and competence,

\footnotetext{
${ }^{1} \mathrm{AfL}$ is an approach to learning where the process of learning is assessed as this occurs-see for instance Willis (2009) for a review of the AfL approach.

${ }^{2}$ However, the context of this study differed from Montgomery's. Students were assessed only on the final outcome of their group work and not on the collaborative process.
} 
and actually achieve enhanced levels of intercultural competence in their graduates or that the end of internationalisation is approaching (Brandenburg and De Wit 2011). This study explores the impact of the various forms of social interactions of a university environment on this development. It contributes to the understanding of the impact of internationalization of higher education on intercultural competence development, and challenges and tests the traditionalist view and its implicit assumption that exposure to diversity leads to intercultural competence development. The research questions how the social environment at a university impacts the development of intercultural competence of students whilst on campus.

\section{Theory and Concepts}

\subsection{The Contact Hypothesis for Intergroup Contact as a Theoretical Framework}

The traditionalist view in higher education on intercultural competence development holds that exposure to diversity will lead to increased intercultural competence. This wide spread view reflects the Contact Hypothesis for Intergroup Contact - in short Contact Hypothesis Theory — which states that exposure to culturally different groups will lead to reduced prejudice (Allport 1954; Amir 1976). Allport concluded that for constructive and positive contact to develop between culturally different individuals in a mixed group, the situation must allow for equal status within the group, common goals, intergroup cooperation, and authority support. Pettigrew (1998) adds a long term perspective to the original Contact Hypothesis Theory. He concluded on the basis of his literature review that the contact needs to have friendship potential and sufficient time to develop, in addition to the four original conditions formulated by Allport. He points to a stage-wise process from initial contact between individuals from mixed backgrounds through established contact to a unified mixed group. Recent research has further enriched the understanding of the theory. Brannon and Walton (2013) found that intergroup contact and a sense of social connectedness increase the interest in the other culture and thereby reduces prejudice and stereotyping. Quality of the contact, salience of group membership, context of the contact, voluntary or forced all influence the impact of the intergroup contact on prejudice and positive and constructive contact. To what extent, why and how positive intergroup contact generalizes to other situations, the entire out group or uninvolved out groups, has not been specified yet through the Contact Hypothesis Theory. One could state that the traditionalist view (Bennett, in Berg et al. 2012) often found in Higher Education implicitly assumes that positive and constructive intergroup contact leads to intercultural competence. The question however is if the process and outcomes as described by the Contact Hypothesis Theory result in the development of intercultural competence. To answer this question, a clear definition of intercultural competence and how this can be measured are necessary. The next paragraphs review the 
construct of intercultural competence, how this can be measured, and propose a tentative model for intercultural competence development that includes the impact of the social environment as specified by the Contact Hypothesis Theory.

\subsection{Defining Intercultural Competence}

A definition which has been widely accepted in the field is Deardorff's (2006) research based definition of intercultural competence and its assessment. Deardorff (2006) defines intercultural competence as behaving and communicating effectively and appropriately in cross-cultural situations, based on one's intercultural knowledge, skills and attitudes, to achieve one's goals to some degree. According to Deardorff, key for intercultural competence development are the personal attitudes like respect for different cultures and values, openness and curiosity which lead to cultural self-awareness, emphatic understanding of other cultures, and the ability and willingness to behave accordingly. Deardorff's model is complementary to the Contact Hypothesis Theory because of the focus on these personal attitudes. Deardorff's definition however has its limitations as it does not specify any levels of competence. The actual learning and the underlying developmental processes are difficult to quantify based on Deardorff's theory. Comparisons between individuals and development over time therefore essentially depend on self-assessment or evaluation of an independent observer. In the next section of this paragraph, the selection of a developmental model for intercultural competence to further frame this research project is discussed, that is in line with the definition of Deardorff (ibid) and that allows for a quantitative assessment of intercultural competence.

\subsection{Measuring the Development of Intercultural Competence}

Although in the literature several models for intercultural competence development can be found (Spitzberg and Changnon 2009), this research project builds on the theory of the Intercultural Development Continuum (IDC) because of its strong research base, and uses the related Intercultural Development Inventory (IDI) as the diagnostic instrument to measure changes in the level of intercultural competence of the participants in this study. The Intercultural Development Continuum has been derived from Bennett's (Bennett 1993, 1998, 2004) Developmental Model for Intercultural Sensitivity (DMIS) in which individuals increasingly are able to accommodate cultural difference in their construction of daily reality. Furthermore, as individuals progress on the developmental continuum, also the 'experience' of cultural difference changes and becomes more complex and integrated into a person's sense of self. The development is described as revolutionary, with distinctly different worldviews and developmental conflicts underlying each stage. Based on 
Table 1 IDI worldviews and development orientations (Hammer 2009)

\begin{tabular}{|c|c|}
\hline \multicolumn{2}{|c|}{ Intercultural development continuum } \\
\hline \multicolumn{2}{|c|}{ Mono-cultural worldview } \\
\hline Denial & $\begin{array}{l}\text { Superficial awareness of cultural difference resulting in disinterest and } \\
\text { avoidance of cultural difference }\end{array}$ \\
\hline Polarization & A judgmental view of cultural difference in terms of 'we versus them' \\
\hline Defense & $\begin{array}{l}\text { An uncritical view towards the own culture as more positive and ideal and an } \\
\text { overly critical view on other values and practices }\end{array}$ \\
\hline Reversal & $\begin{array}{l}\text { An overly critical view towards the own cultures values and practices and an } \\
\text { uncritical view of the other culture's value and practices }\end{array}$ \\
\hline \multicolumn{2}{|l|}{ Transition } \\
\hline Minimization & $\begin{array}{l}\text { Cultural commonalities, universal values and principles are highlighted } \\
\text { masking a deeper recognition and appreciation of cultural difference }\end{array}$ \\
\hline \multicolumn{2}{|c|}{ Global worldview } \\
\hline Acceptance & $\begin{array}{l}\text { Appreciation of other cultures and the acceptance that other cultures include } \\
\text { both differences and commonalities compared to the own culture }\end{array}$ \\
\hline Adaptation & $\begin{array}{l}\text { The capability to shift cultural perspectives and change behavior in culturally } \\
\text { appropriate and authentic ways }\end{array}$ \\
\hline
\end{tabular}

the theory of the DMIS, the Intercultural Development Inventory (IDI) has been constructed (Hammer et al. 2003). The research findings resulting from the IDI led to the adaptation of the DMIS by Hammer $(2009,2011,2012)$. He renamed the model the Intercultural Development Continuum (IDC), which currently describes five consecutive and distinctive orientations of intercultural awareness and competence. In Table 1 an overview of the developmental orientations identified in the IDC are given.

The related IDI is a psychometric self-assessment instrument and repeatedly has seen confirmatory testing on content validity, cross-cultural validity and reliability (Hammer 2011). The IDI measures how a person perceives the own level of intercultural competence (PO), and the actual development orientation (DO), indicating the real level of intercultural competence. The orientation gap (OG) is the difference between the PO and the DO scores. According to Hammer et al. (2003), an orientation gap larger than seven IDI points indicates a person does not have a realistic perception of the own level of intercultural competence. The IDI includes the ability to insert customized questions.

\subsection{A Tentative Model for Intercultural Competence Development}

To test the traditionalist' view in Higher Education on intercultural competence development and synthesizing the literature reviewed above in this research project, a tentative model has been developed that explains the relationship over time 
Fig. 1 The extended contact hypothesis model for intercultural competence development

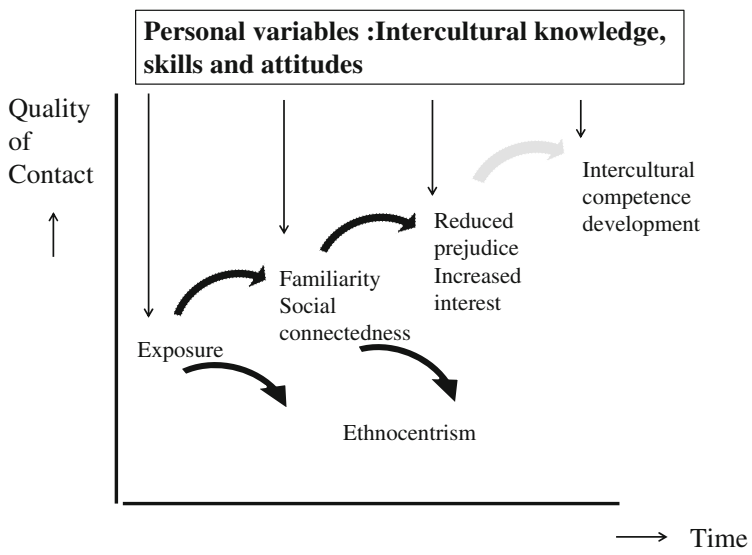

between the quality of the contact or interaction between students in the university environment and the personal variables and history of these students. The tentative model expresses that over time intercultural competence is developed as a result of the interaction, which includes the type and perceived quality (satisfaction) of the contact as specified by earlier research (Allport 1954; Pettigrew 1998); and the personal variables as specified by Deardorff $(2006,2009 a)$, which include intercultural knowledge, attitudes and skills. The biographic factors which have been identified in the literature on study abroad as key factors influencing intercultural competence development are language ability, preparation for study abroad, independent living and previous experience abroad. These factors form part of the individual biography and are included in the personal variable set. The model is grounded on Contact Hypothesis Theory and extended with the research based models of intercultural competence of Deardorff. Figure 1 describes this extended model. The focus in this research project is on understanding the relationship between the contact variables: type of contact, satisfaction and frequency with that contact on intercultural competence development.

\section{The University Case}

The study has taken place between August 2010 and April 2011 at a non-Anglophone European university that is renowned for its international reputation. Most undergraduate and post graduate programs include an international or European dimension or orientation in the curriculum and are fully English taught. ${ }^{3}$ During their study, the students have contact with students from different cultures in their tutorial groups and classes; they are taught by culturally diverse staff and have

${ }^{3}$ Except Law and Medicine. 
the opportunity for an internship or study abroad. The university has successfully implemented an English language policy for students and for staff, and offers additional English language training for both groups. Most information and policy documents are available in English and the language used in governance is English, unless. Student services for international students are fully integrated in the standing organization. Study associations and sports clubs are open to all students, and their communication primarily is in English as well. At the time of the study, the student population of university $X$ consists of approximately $45 \%$ foreign students and $55 \%$ home students. This international reputation has been confirmed both in international university rankings and an independent quality assurance agency, in terms of its internationalized curriculum, its international student and staff populations, and global employability of its graduates.

\section{Method}

A pre/post test observational design has been applied with a period of 10 months. This type of design is referred to as quasi-experimental design, in which real world events produced by the unfolding political and social processes' (Brady and Collier 2004, p. 302) constitute the treatment between the pre- and the post test. The quality of the social contact during the test period can be seen as the treatment.

The target group is first year master students. Masters entrants have already successfully completed a university degree and gone through transformative experiences which potentially could have influenced the impact of the internationalized university's social environment on intercultural competence development (Hammer et al. 2003).

The fundamental research question, how the social environment at a university impacts the development of intercultural competence of students whilst on campus, has been contextualized for this study into two measurable research questions. Does the level of intercultural competence of first year master students increase whilst on campus during the first nine months of study at University? How do the social interactions between respondents and other students and staff inside or outside the curriculum impact the development of intercultural competence of first year master students?

The Intercultural Development Inventory (IDI v.3) has been selected as method of inquiry. A questionnaire was considered completed when all 50 items on the IDI were completed. The IDI scale generates IDI scores between 50 and 145 points which have been normalized around the population mean of 100 IDI points at the median in the minimization interval. Table 2 gives the interval ranges for each of the five development orientations, and their relative expected weight. ${ }^{4}$

\footnotetext{
${ }^{4}$ The expected population distribution is reported by Hammer (2011).
} 
Table 2 IDI development orientations; their respective abbreviations and interval ranges; and the relative expected weight for the normalized IDI population distribution

\begin{tabular}{l|l|l|l}
\hline IDI orientation & Abr. & IDI scores & \% weight \\
\hline Denial & D & $<70$ & 2.28 \\
\hline Polarization & P & $70-84.99$ & 13.59 \\
\hline Minimization & M & $85-114.99$ & 68.26 \\
\hline Acceptance & Acc & $115-129.99$ & 13.59 \\
\hline Adaptation & AD & $130-145$ & 2.28
\end{tabular}

In addition to 50 items that measure intercultural competence, the IDI also includes a maximum of six customized questions and eight standard open questions. The customized questions in this study have been formulated in accordance with the specific focus of this study regarding the quality of the contact and the personal variables as described in the theoretical paragraph.

The final sample consists of 108 respondents, which is representative for the total population of first year master students. ${ }^{5}$ The analysis of the response pattern suggests there are no intervening variables that affected the pre-test and post-test measurement.

To assess the impact of the social environment of the university on the development of intercultural competence, the post-test respondents have been allocated into two different test groups; a benchmark group (BM) consisting of first year master students continuing from an undergraduate program at the university $(n=31)$ and a quasi-experimental group consisting of first year master students that are new entrants (NE) to the university $(n=54)$. For a number of respondents $(n=23)$ it could not be identified if they were new to the university. ${ }^{6}$ This group is referred to as the 'continuation/new unknown' group (UnK). The research resulted in various data sets, either directly generated by the IDI or constructed based on the IDI data.

\section{Results}

\subsection{Development of Intercultural Competence After Nine Months of Study}

Does the level of intercultural competence of first year master students increase whilst on campus during the first nine months of study at University? The results of the IDI indicate that the development orientation of the total sample lies in early

\footnotetext{
${ }^{5} 95 \%$ confidence with a $9.2 \%$ range.

${ }^{6}$ Continuation from undergraduate to postgraduate programmes ranges between 40 and $60 \%$. Research indicates that $50 \%$ of bachelor students considers continuation (Source Annual Report 2010).
} 
Minimization at the pre-test, as well as at the post test assessment. The benchmark group and the unknown group score at the cusp of Minimization at the pre- and the post-test. The mean score of the new entrants is in Minimization. The mean IDI scores of the benchmark, the new entrants and the unknown groups for the pre-test and the post-test are given in Table 2 .

The data in Fig. 2 inform the mean scores of each of the three groups and the total sample slightly decreased at the post-test. However, the development orientation is unchanged and remains in early Minimization. Regardless whether the respondents progress from an undergraduate program or are new to the university, $\mathrm{t}$-tests for paired sample means could not confirm significant differences within each of the groups between the pre-test and the post-test. ${ }^{7}$ Furthermore, no significant differences in IDI scores between the groups can be observed after 10 months. ${ }^{8}$

The IDI scores indicate the developmental orientation of the respondents. The IDI orientations of the benchmark and the group of new entrants compared to the population distribution for the pre-test are given in Fig. 3. The two test groups 9 appear to deviate from the population distribution. In the benchmark group, Denial and Polarization seem over-represented, and in the group of the new entrants Polarization seems over-represented. The global worldviews Acceptance and Adaptation are under-represented in the pre-test.

The post-test distribution seems to suggest the distributions of the benchmark group and the group of new entrants across the IDI Orientations have become more similar, however still deviate from the population distribution. Although there are some exceptions, in Fig. 4 a general tendency towards Polarization can be observed.

A series of Kolmogorov-Smirnov test for small samples has been performed, assessing whether the observed ${ }^{10}$ frequencies of the benchmark group, the group of new entrants and the total sample match the population distribution. The tests confirm that Polarization is over-represented and Acceptance and Adaptation under-represented for both groups at the pre-test, as well as at the post-test. A tendency towards polarization could not be confirmed ${ }^{11}$ for the test groups separately. However, at the level of the total sample, a significant difference ${ }^{12}$ has

\footnotetext{
${ }^{7} \mathrm{BM}$ group: $\mathrm{T}=0.18 ; \mathrm{df}=30 ; \mathrm{p}=0.86 . \mathrm{NE}$ group: $\mathrm{T}=1.35 ; \mathrm{df}=53 ; \mathrm{p}=0.18$. Unknown group: $\mathrm{T}=1.52 ; \mathrm{df}=22 ; \mathrm{p}=0.14$.

${ }^{8}$ ANOVA single Factor Analysis; $\mathrm{T} 1: \mathrm{F}=0.78, \mathrm{p}=0.46 ; \mathrm{T} 2: \mathrm{F}=0.45, \mathrm{p}=0.64$.

${ }^{9}$ The group of respondents of which it is not known whether they are new to the university has been excluded from the interval analysis because of the $n<30$ and because the $t$-tests concluded there were no significant differences between the Unknown and the two test groups.

${ }^{10} \mathrm{~A}$ value of 0.5 has been added to each of the cells in the frequency table to avoid the empty cells. According to Agresti (1990), this enables the statistical analysis but does not influence the actual outcome, (p. 54). The reworked number of respondents is referred to as $\mathrm{n}^{\prime}$ and equals 33.5.

${ }^{11} \mathrm{McNemar}$ 's test for correlated samples failed to confirm statistical significance. In the benchmark group one case, in the group of new entrants three cases have been eliminated to enable this test. These cases were considered outliers.

${ }^{12}(\mathrm{p}=4.34 \mathrm{E}-03)$.
} 


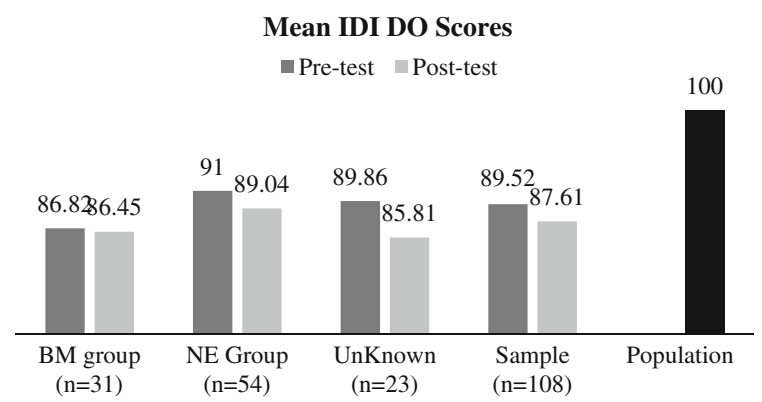

Fig. 2 The mean IDI raw DO scores of the benchmark group, the new entrants group and the Unknown compared to sample and the population mean

Fig. 3 The relative distribution of the pre-test IDI scores across the IDI orientations
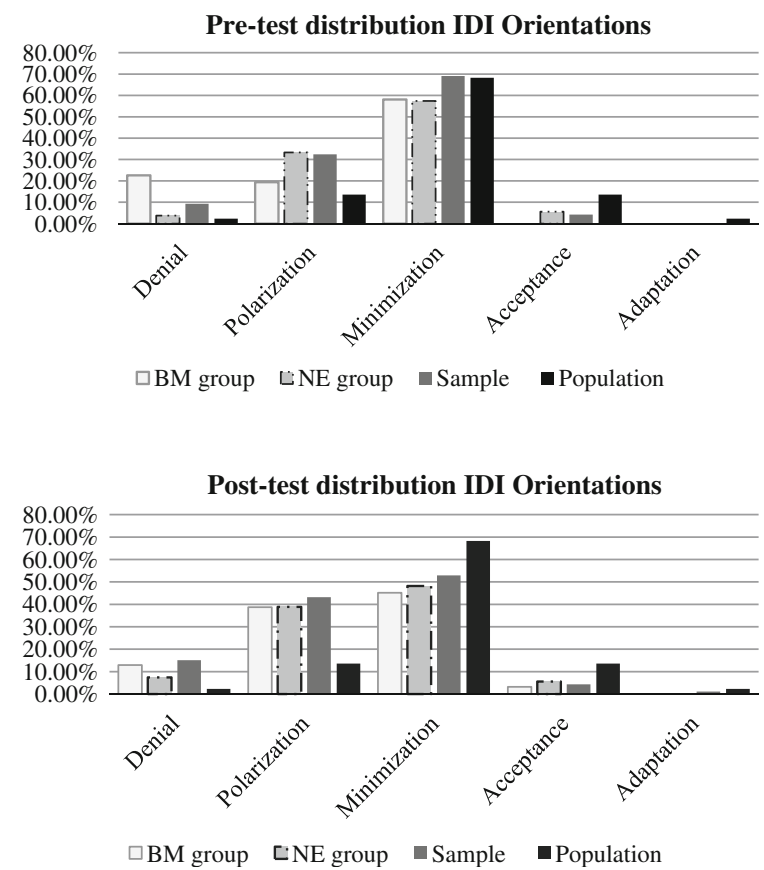

BM group $[N E$ group Sample $\quad$ Population
Fig. 4 The relative distribution of the post-test IDI scores across the IDI orientations

been found indicating that more respondents with a pre-test score in Minimization regressed to Polarization in the post-test than expected ${ }^{13}$ if change had been random.

\footnotetext{
${ }^{13} \mathrm{~A}$ random probability of change in development orientation refers to a $50 \%$ chance that a respondent remains in a developmental orientation and a $-50 \%$ chance that a respondent increases or decreases in developmental orientation.
} 
In the benchmark group, change in development orientation and the direction of that change ${ }^{14}$ occur randomly. ${ }^{15}$ In the group of new entrants, significantly fewer participants changed in IDI orientation then if change had been random ${ }^{16}$; the direction of change however is random. For the total sample, the number of respondents who changed in orientation is lower than expected then if change had been random ${ }^{17}$; in case change takes place, the direction is random.

The range of available IDI Orientations within the sample at the pre-test and the post-test is relatively narrow primarily in the Mono-cultural and Minimization areas of the IDI scale.

The results so far indicate that the level of intercultural competence in terms of IDI scores does not increase in the 9 month study period, regardless whether respondents are new to the university. However, a tendency in development orientation towards Polarization has been confirmed. To better understand this tendency, an analysis for each of the pre-test IDI Orientation has been performed. The T-test for correlated samples confirms that the group of respondents $(n=10)$ with a pre-test development orientation of Denial progressed in the IDI scores at the post-test. ${ }^{18}$ Six of these respondents progressed towards Polarization; one towards Minimization. No significant change in IDI scores has been identified for the group of respondents with a pre-test development orientation in Polarization; although six respondents actually regressed into Denial; and three respondents progressed towards Minimization. The group of respondents with a pre-test development orientation in Minimization regressed to Polarization. ${ }^{19}$ This primarily can be attributed to the subgroup of respondents in early Minimization. ${ }^{20}$ No significant change in IDI scores has been identified for the group of respondents who scored in Acceptance at the pre-test.

\subsection{Polarization}

Polarization is more salient in the test sample of first year master students than expected. Polarization can take the form of Defence and Reversal. To better understand how this group views diversity, their scores are further analyzed.

The respondents with a development orientation in Polarization and at the cusp of Polarization constitute one third ${ }^{21}$ of the total sample. Of this group, for $52 \%$ of

\footnotetext{
${ }^{14}$ The direction of change refers to a decrease or an increase in development orientation.

${ }^{15}$ Confirmed by exact binominal calculations.

${ }^{16}(\mathrm{p}=0.04)$.

${ }^{17}(\mathrm{p}=4.53 \mathrm{E}-03)$.

${ }^{18}(\mathrm{p}=4.12 \mathrm{E}-05)$.

${ }^{19}(\mathrm{p}=1.45 \mathrm{E}-02)$.

${ }^{20}(\mathrm{p}=3.80 \mathrm{E}-02)$.

${ }^{21} 26.7$ and $5.9 \%$ respectively.
} 
the respondents Defence is the primary response to diversity; for $48 \%$ of this group Reversal is the primary response. ${ }^{22}$ In Fig. 5 the distribution between Defence and Reversal is given. Furthermore, the analysis of the individual IDI reports of respondents in Polarization informs that the majority of individual DefenceReversal scores range between 40 and $60 \%$.

This finding implies that the respondents with a development orientation in Polarization are undecided in their response to diversity.

\subsection{Perception of the Own Level of Intercultural Competence}

Do the respondents have a realistic view on the own level of intercultural competence? The scores for the Orientation Gap inform that all respondents substantially overestimate their own level of intercultural competence. The Orientation Gap (OG) for each of the groups is larger than seven IDI points. Figure 3 gives the scores for the Orientation Gaps of the two test groups, the unknown group and the total sample; pre- and post-test (Fig. 6).

Even though for each of the groups the OG seems to increase after 10 months, this has only been confirmed ${ }^{23}$ for the sample as a whole.

\subsection{Impact of the Social Environment}

How do the social interactions between respondents and other students and staff inside or outside the curriculum impact the development of intercultural competence of first year master students?

Overall, ${ }^{24}$ the total sample was very satisfied (19\%) or satisfied (47\%) with the cooperation with the staff. The cooperation with students from other cultures was evaluated as very good $(15 \%)$ or good $(44 \%)$. For $11 \%$ of the respondents the cooperation was neither good nor bad. Contact with other students in the education program was the most important for respondents in terms of improving one's intercultural competence (39\%); $24 \%$ indicated contact with other students outside the education program was the most important. Contact with academics or with citizens of the city each was most important to $4 \%$ of the respondents. The average scores per question assessing the contact variables per IDI Orientation are given in Table 3.

\footnotetext{
${ }^{22}$ IDI group report post test.

${ }^{23} \mathrm{p}=0.05$; one tailed.

${ }^{24}$ Not all respondents fully completed the contexting questions.
} 


\section{Polarization}

- Defense $\quad$ Reversal

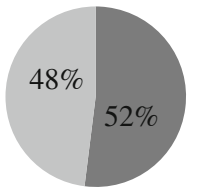

Fig. 5 The percentages of defence and reversal within the polarization orientation

Fig. 6 The orientation gap of the benchmark group, the new entrants group and the unknown group; pre- and post-test

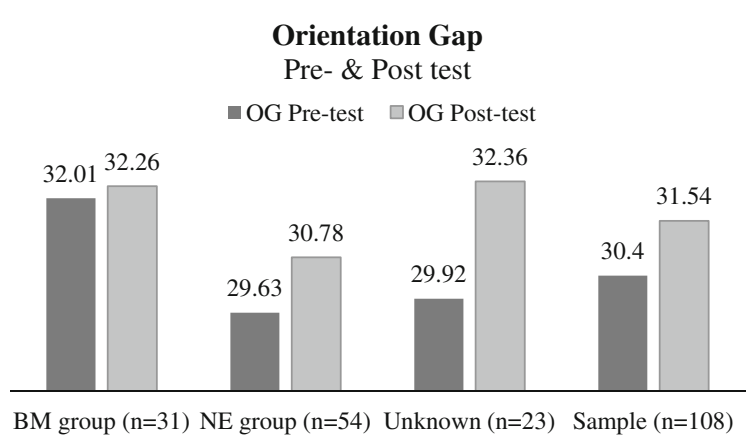

Table 3 The evaluation of the contact variables per IDI orientation

\begin{tabular}{l|l|l|l|l}
\hline & \multicolumn{3}{l}{ IDI orientations } \\
\hline Contact variables & $\begin{array}{l}\text { Denial } \\
\mathrm{n}=10\end{array}$ & $\begin{array}{l}\text { Polarization } \\
\mathrm{n}=30\end{array}$ & $\begin{array}{l}\text { Minimization } \\
\mathrm{n}=64\end{array}$ & $\begin{array}{l}\text { Acceptance } \\
\mathrm{n}=4\end{array}$ \\
\hline Cooperation staff & 1.63 & 1.18 & 1.83 & 1.8 \\
\hline $\begin{array}{l}\text { Cooperation culturally different } \\
\text { students }\end{array}$ & 2 & 1.32 & 1.71 & 2.25 \\
\hline Most important contact & $\begin{array}{l}\text { Students } \\
100 \%\end{array}$ & $\begin{array}{l}\text { Students } \\
100 \%\end{array}$ & $\begin{array}{l}\text { Students } \\
86 \%\end{array}$ & $\begin{array}{l}\text { Students } \\
75 \%\end{array}$ \\
\hline Frequency & 2.25 & 1.22 & 1.95 & 1.5 \\
\hline & Legend \\
\hline Cooperation staff & Very good (1) - good (2) \\
\hline $\begin{array}{l}\text { Cooperation culturally different } \\
\text { students }\end{array}$ & Good (2)-neither good nor bad (3) \\
\hline Frequency & Every day (1) - a few times a week (2) \\
\hline
\end{tabular}

Although the number of respondents in Denial and Acceptance are small and the results have to be interpreted with caution, the data seem to suggest that the respondents in Polarization are the most satisfied with the cooperation with staff and students from other cultures; that contact with other students is deemed the most important and that they engage with students from other cultures most frequently. 


\section{Conclusions}

This study explores whether the level of intercultural competence of first year master students increases whilst on campus during the first nine months of study at the University, and how the social interactions between respondents and other students and staff inside or outside the curriculum impact the development of intercultural competence. It can be concluded that first year master students do not progress in the level of intercultural competence as measured by the IDI after 9 month of study; regardless whether they progress from an undergraduate program or are new to the university; and despite the fact that they study in an internationalized university environment. The implicit assumption of many university leaders has to be rejected.

Regarding the impact of the internationalized social environment, it can be concluded that the social interactions inside and outside the curriculum do not lead to an increase of intercultural competence per se, even though respondents are satisfied with the cooperation and have daily or weekly contact. The reported high level of satisfaction with the cooperation with students who are culturally different and its perceived importance for intercultural competence development indicate that students may not truly recognize cultural difference, and primarily work with what they have in common. Although this leads to positive intergroup experiences, actual intercultural learning does not take place. The tentative extended Contact Hypothesis Model proved useful for designing and understanding the results of this study, it is however insufficient to actually predict intercultural competence development.

On the other hand, the findings do suggests that students representing the more salient worldview(s) to diversity on campus impact the development of other students, and that the dominant group functions as a role model for other students on campus on how to respond to diversity. In this case the available range of IDI orientations on campus is narrow and primarily includes the Mono-cultural orientations and Minimization. Polarization is more salient in the group of first year master students than should be expected based on the population distribution, and a tendency towards Polarization has been confirmed. Respondents in Denial progressed towards Polarization, and respondents in early Minimization regressed towards Polarization. This analysis seems to suggest that the master students in Denial benefit from the presence of advanced levels of intercultural competence; master students in Minimization, and more specific in early Minimization, seem the suffer from lower levels of intercultural competence. The first year master students with the higher levels of intercultural competence do not seem affected by the presence the lower levels of intercultural competence. However, the impetus to progress to more inclusive global mindsets seems to be lacking, as opportunities for first year master students to learn from more advanced levels of intercultural competence on campus are not available.

Furthermore, it can be concluded that the students in Polarization in this study are undecided in their response to diversity. In some situations they will be 
uncritical towards the own culture and overly critical to other values and practices, whilst in other situations they will be overly critical towards the own culture and uncritical towards other values and practices. This indicates that the students in Polarization, in principle, are aware of and open to diversity, however they need guidance on how to appropriately interpret and evaluate the own and others values and practices.

First year master students substantially overestimate their level of intercultural competence, both at the pre-test and the post test. Furthermore, the Orientation Gap does not change between the pre-test and the post-test.

\section{Discussion}

The conclusions of this study concur with the conclusions in the literature regarding study abroad and student exchange. Exposure to diversity does not lead to the development of intercultural competence per se and regression may occur (Berg et al. 2012), especially when lower levels of intercultural competence are more salient in the institution and the range of available orientations is narrow. If universities truly intend to support their students to become global ready graduates, a pedagogical approach is needed that is intentional and helps students to recognize and reflect on cultural differences and commonalities; and that guides them to effectively and appropriately address their differences. Such a pedagogical approach needs to build on an understanding and diagnostic of the level of intercultural competence on arrival, as this determines the specific stage appropriate learning objectives (Gregersen-Hermans and Pusch 2012), and needs to embed the contact variables in the internationalized learning environment as specified by the Contact Hypothesis Model.

This study confirms a convergence towards the more salient worldview on campus. A further implication for university leaders therefore is to include targets in their internationalization strategies for raising the level of intercultural competence of all constituents - students and staff — on campus. This study highlights that students substantially and without exception overestimated their own level of intercultural competence. At the strategic level, this conclusion has implications for the research on the impact and effectiveness of internationalization, especially where this research relies on self-reports of students. Additional quantitative and qualitative methods are advised for assessing student learning, as well as the effectiveness of the internationalization strategy.

The post-test scores on the IDI confirmed the tendency towards the dominant majority, which in this case study are the polarization and early minimization orientations of the Intercultural Development Continuum. Although the following interpretation at this point in time only can be tentative because of the sample size, the result can be explained through the Field Theory of Social Psychology (Lewin 1951) and the process of co-orientation during cross cultural adaptation (Alred and Byram 2002; Byram 1997, 2003; Fantini 1995; Spitzberg and Changnon 2009). 
According to the Field Force Theory, the social environment at the university and its salient level of intercultural competence is a state of equilibrium resulting from driving forces and restraining forces. Internationalization can be seen as the driving force aiming to progress the level of intercultural competence of its students. The restraining forces are possible organizational inertia (Hawanini 2011) or the lack of organizational capability to deliver on intercultural competence development (Gregersen-Hermans 2014). The pressure of the social environment and the need of an individual to fit in with the dominant majority as a survival strategy in an unfamiliar environment may have functioned as a confounding variable and hindered intercultural competence development in terms of the IDI. Increasing the driving forces whilst not addressing the restraining forces proved not sufficient to achieve a social environment in the university, which spurs intercultural competence development. Implication for university leaders is that strategies for internationalization need to include the identification of constraining factors and measures to redress or diminish these.

This study is based on a single case study so the results and conclusions have to be interpreted with caution. In this report the possible impact of previous experience abroad, language of instruction and nationality has not been included. The composition of the test group in terms of national background may be the result of an unintended selection bias caused by different patterns of mobility between Dutch, EU and non-EU students at the time of the research. Additional analysis needs to be undertaken. Furthermore, the assessment of the level of intercultural competence in this study relied on a single measure, the IDI. According to Deardorff and Jones (2012), for a more in-depth analysis of the level of intercultural competence a multiple assessment approach is essential. Future research on the impact of the social interactions on campus needs to take this into account.

The study highlights the need for more in-depth research into the actual development process that is taking place in an internationalized university, be it inside the classroom or extracurricular; not only relying on self-reports of students, but combining qualitative assessment methods development with quantitative measurement of intercultural competence; and also considering the social context of the university environment and the organizational capability to deliver on intercultural competence development.

Open Access This chapter is distributed under the terms of the Creative Commons Attribution Noncommercial License, which permits any noncommercial use, distribution, and reproduction in any medium, provided the original author(s) and source are credited.

\section{References}

Agresti, A. (1990). Categorical data analysis. New York: Wiley.

Alfranseder, E., Fellinger, J., \& Taivere, M. (2011). Evaluate your experience: Research report of the ESN survey 2010. Brussels: Erasmus Student Network.

Allport, G. (1954). The nature of prejudice. Addison-Wesley, MA: Reading. 
Alred, G., \& Byram, M. (2002). Becoming an intercultural mediator: A longitudinal study of residence abroad. Journal of Multilingual and Multicultural Development, 23(5), 339-352.

Amir, Y. (1976). The role of intergroup contact in change of prejudice and race relations. In P. A. Katz (Ed.), Towards the elimination of racism (pp. 245-280).

Beelen, J. (Ed.). (2007). Implementing internationalization at home (2nd ed.). Amsterdam: EAIE.

Bennett, M. J. (1993). Toward ethnorelativism: A developmental model of intercultural sensitivity. In R. Michael Paige (Ed.), Education for the intercultural experience (pp. 21-71). Yarmouth, ME: Intercultural Press.

Bennett, M. J. (1998). Intercultural communication: A current perspective. Basic Concepts of Intercultural Communication: Selected Readings, 1-34.

Bennett, M. J. (2004). Becoming interculturally competent. Toward multiculturalism: A reader in multicultural education, 2, 62-77.

Berg, M. V., Paige, R. M., \& Lou, K. H. (2012). Student learning abroad: What our students are learning, what they're not, and what we can do about it. LLC: Stylus Publishing.

Brady, H. E., \& Collier, D. (2004). Rethinking social inquiry. Diverse tools, shared standards. Oxford: Rowman and Littlefield Publishers. Inc.

Brandenburg, U., \& De Wit, H. D. (2011). The end of internationalization. In de Wit (Ed.), Trends, issues and challenges of higher education (pp. 27-28). Amsterdam: CAREM.

Brannon, T. N., \& Walton, G. M. (2013). Enacting cultural interests how intergroup contact reduces prejudice by sparking interest in an out-group's culture. Psychol. Sci., 24(10), 19471957.

Byram, M. (1997). Teaching and assessing intercultural communicative competence. Clevedon: Multilingual Matters.

Byram, M. (2003). On being 'bicultural' and 'intercultural'. In G. Alred, M. Byram, \& M. P. Fleming (Eds.), Intercultural experience and education (Vol. 2, pp. 50-66). Clevedon: Multilingual Matters.

de Wit, H. (2011). Internationalization of higher education: Nine misconceptions. International Higher Education, 64, 6-7.

Deardorff, D. K. (2006). Identification and assessment of intercultural competence as a student outcome of internationalization. Journal of Studies in International Education, 10(3), 241-266.

Deardorff, D. K. (2009a). Synthesizing conceptualizations of intercultural competence: A summary and emerging themes. In D. Deardorff (Ed.), The Sage handbook of intercultural competence. Thousand Oaks, CA: Sage Publications.

Deardorff, D. K. (Ed.). (2009b). The Sage handbook of intercultural competence. Thousand Oakes, CA: Sage Publications.

Deardorff, D., \& Jones, E. (2012). Intercultural competence: An emerging focus in international higher education. In D. Deardorff, H. de Wit, J. Heyl, \& T. Adams (Eds.), The SAGE handbook of international higher education. Thousand Oaks, CA: SAGE publications.

Deardorff, D. K., de Wit, H., Heyl, J., \& Adams, T. (2012). The Sage handbook of international higher education. Thousand Oakes, CA: Sage Publications.

Egron-Polak, E., \& Hudson, R. (2014). Internationalization of higher education: Growing expectations, fundamental values. Paper presented at the IAU 4th Global Survey.

European University Association. (2013). Internationalization in European higher education: European policies, institutional strategies and EUA support. Brussels: EUA.

Fantini, A. E. (1995). Introduction-language, culture and world view: Exploring the nexus. International Journal of Intercultural Relations, 19(2), 143-153.

Graf, A. (2004). Assessing intercultural training designs. Journal of European Industrial Training, 28(2-3-4), 199-214.

Gregersen-Hermans, J. (2014). The missing link in intercultural competence development: The university's organizational capability to deliver (Vol. 78). Chestnut Hill, MA: The Boston College for Higher Education.

Gregersen-Hermans, J., \& Pusch, P. (2012). How to design and assess an intercultural learning experience. In K. Berardo \& D. Deardorff (Eds.), Building intercultural competence. Innovative activities and models. Sterling Virginia: Stylus Publishing. 
Hammer, M. R. (2009). The intercultural development inventory. In M. A. Moodian (Ed.), Contemporary leadership and intercultural competence (pp. 203-218). Thousand Oaks, CA: Sage.

Hammer, M. R. (2011). Additional cross-cultural validity testing of the intercultural development inventory. International Journal of Intercultural Relations, 35, 474-487.

Hammer, M. (2012). The intercultural development inventory: A new frontier in assessment and development of intercultural competence. In M. Vande Berg, R. M. Paige, \& K. H. Lou (Eds.), Student learning abroad (pp. 115-136). Sterling, VA: Stylus Publishing.

Hammer, M. R., Bennett, M. J., \& Wiseman, R. (2003). Measuring intercultural sensitivity: The intercultural development inventory. International Journal of Intercultural Relations, 27(4), 421-443.

Harrison, N., \& Peacock, N. (2010). Cultural distance, mindfulness and passive xenophobia: Using Integrated Threat Theory to explore home higher education students' perspectives on "internationalization at home". British Educational Research Journal, 36(6), 877-902.

Hawanini, G. (2011). The internationalization of higher education institutions. A critical review and a radical proposal. Paris: INSEAD Working Paper.

Jones, E. (2010). 'Don't worry about the worries': Transforming lives through international volunteering. In E. Jones (Ed.), Internationalization and the student voice: Higher education perspectives. London: Routledge.

Kimmel, K., \& Volet, S. (2012). University students' perceptions of and attitudes towards culturally diverse group work: Does context matter? Journal of Studies in International Education.

Krzaklewska, E., \& Krupnik, S. (2006). Research report. The experience of studying abroad for exchange students in Europe. Erasmus Student Network in cooperation with Petrus Communications: Brussels.

Leask, B. (2009). Using formal and informal curricula to improve interactions between home and international students. Journal of Studies in International Education, 13(2), 205-221.

Leask, B. (2010). Beside me is an empty chair (Vol. 1). London: Routledge.

Lewin, K. (1951). Field theory in social science: Selected theoretical papers.

Li, M., \& Campbell, J. (2008). Asian students' perceptions of group work and group assignments in a New Zealand tertiary institution. Intercultural Education, 19(3), 203-216.

Littrell, L. N., \& Salas, E. (2005). A review of cross-cultural training: Best practices, guidelines, and research needs. Human Resource Development Review, 4(3), 305-334.

Maastricht University. (2010). Annual Report. Downloaded from www.maastrichtuniversity.nl.

Mestenhauser, J. A., \& Ellingboe, B. J. (1998). Reforming the higher education curriculum internationalizing the campus. Phoenix, AZ: Oryx Press.

Mestenhauser, J. A., Grunzweig, W., \& Rinehart, N. (Eds.). (2003). Rockin in red square: Critical approaches to international education in the age of the cyberculture. Münster: Lit Verlag.

Montgomery, C. (2009). A decade of internationalization: Has it influenced student's views of cross-cultural group work at university? Journal of Studies in International Education, 13(2), 256-270.

Montgomery, C. (2010). Understanding the international student experience. Basingstoke: Palgrave Macmillan.

Nilsson, B., \& Otten, M. (2003). Internationalization at home (Special issue). Journal of Studies in International Education, 7(1).

Paige, M. R., Jacobs-Cassuto, M., Yershova, Y. A., \& DeJaeghere, J. (2003). Assessing intercultural sensitivity: An empirical analysis of the Hammer and Bennett Intercultural Development Inventory. International Journal of Intercultural Relations, 27(4), 467-486.

Paige, R. M., Fry, G. W., Stallman, E. M., Josić, J., \& Jon, J. E. (2009). Study abroad for global engagement: The long-term impact of mobility experiences. Intercultural Education, 20(sup1), S29-S44.

Peppas, S. C. (2005). Business study abroad tours for non-traditional students: An outcomes assessment. Frontiers The Interdisciplinary Journal of Study Abroad, 11, 143-163.

Pettigrew, T. F. (1998). Intergroup contact theory. Annual Review of Psychology, 49(1), 65-85. 
Smith, R. A., \& Khawaja, N. G. (2011). A review of the acculturation experiences of international students. International Journal of Intercultural Relations, 35(6), 699-713.

Spitzberg, B. H., \& Changnon, G. (2009). Conceptualizing intercultural competence in Deardorff D.K. Thousand Oaks, CA: Sage Publications, Inc.

Teekens, H. (2006). Internationalization at home: A background paper. In H. Teekens (Ed.), Internationalization at home: A global perspective. Nuffic: Nuffic.

Teekens, H. (2007). Internationalization at home: Ideas and ideals: European Association for International Education.

Teichler, U. (1999). Research on the relationships between higher education and the world of work: Past achievements, problems and new challenges. Higher Education, 38(2), 169-190.

Teichler, U. (2007a). Die Internationalisierung der Hochschulen. Neue Herausforderingen und Strategien. Frankfurt/New York: Campus Verlag.

Teichler, U. (2007b). Higher education systems. Conceptual frameworks, comparative perspectives, empirical findings. In Altbach (Ed.), Global perspectives on higher education series (Vol. 9). Rotterdam/Taipei: Sense Publishers.

Teichler, U., Ferencz, I., \& Wächter, B. (2011). Mapping mobility in European higher education (Vol. 1). Brussels: Overview and Trends.

Thom, V. (2010). Mutual cultures: Engaging with interculturalism in higher education. In E. Jones (Ed.), Internationalization and the student. Voice Higher education perspectives. London: Routledge.

Van der Wende, M. (2002). Higher education globally: Towards new frameworks for research and policy.

Van Rooyen, M. (Ed.). (2008). Marketing your institution internationally. Amsterdam: European Association for International Education.

Van Vught, T., \& Rogers, (Eds.). (2006). The impact of tuition fees on international student recruitment. Amsterdam: European Association for International Education.

Vande Berg, M., Connor-Linton, J., \& Paige, R. M. (2009). The Georgetown consortium project: Interventions for student learning abroad. Frontiers: The Interdisciplinary Journal of Study Abroad, 18, 1-75.

Wächter, B., \& Ferencz, I. (2012). Student mobility in Europe: Recent trends and implications of data collection. The Netherlands: Springer. 